Int. J. Dev. Biol. 62: 183-194 (2018)

https://doi.org/10.1387/ijdb.180038sg

\title{
Insights into neural crest development from studies of avian embryos
}

\author{
SHASHANK GANDHI and MARIANNE E. BRONNER* \\ Division of Biology and Biological Engineering, California Institute of Technology, Pasadena, USA
}

\begin{abstract}
The neural crest is a multipotent and highly migratory cell type that contributes to many of the defining features of vertebrates, including the skeleton of the head and most of the peripheral nervous system. 150 years after the discovery of the neural crest, avian embryos remain one of the most important model organisms for studying neural crest development. In this review, we describe aspects of neural crest induction, migration and axial level differences, highlighting what is known about the underlying gene regulatory mechanisms. Past and emerging technologies continue to improve the resolution with which we can examine important questions of neural crest development, with modern avian molecular embryology continuing to make important contributions.
\end{abstract}

KEY WORDS: neural crest, migration, genetic toolbox, multipotent, neural plate border

\section{Introduction}

The neural crest is a transient, multipotent stem cell population unique to vertebrates. Induced at the border of the neural plate and the non-neural ectoderm, this cell population initially resides in the elevating neural folds as neurulation progresses and subsequently within the dorsal neural tube (Fig. 1). Shortly after neural tube closure in avian embryos, neural crest cells undergo an epithelialto-mesenchymal transition (EMT), losing their cell-cell contacts and transforming into a migratory cell type, distinct from both the neural tube and epidermal cells (Bronner and Simões-Costa, 2016; Le Douarin and Kalcheim, 1999; Hall, 2009; Sauka-Spengler and Bronner-Fraser, 2008; Steventon et al., 2005). Post EMT, these cells migrate extensively throughout the embryo along distinct pathways, exhibiting both collective and individual cell migration behavior in response to environmental cues and morphogenetic signals. They subsequently give rise to numerous cell types, including melanocytes of the skin, craniofacial cartilage and bones, smooth muscle, Schwann cells, and sensory and autonomic neurons of the peripheral nervous system (Le Douarin and Kalcheim, 1999; Le Douarin and Teillet, 1971; Dupin et al., 2006; Grenier et al., 2009; Hall, 2009; Kirby and Hutson; Minoux and Rijli, 2010; Theveneau and Mayor, 2011). Despite the fact that the neural crest is derived from the ectoderm, it has been referred to as the fourth germ layer due to its ability to migrate long distances and differentiate into such a plethora of derivatives (Le Douarin and Dupin, 2014; Hall, 2000; Shyamala et al., 2015).
The history of neural crest research dates back 150 years, when the Swiss anatomist Wilhelm His, Sr., identified a region at the border of the neural tube and the non-ectoderm in early stage chick embryos that differentiated into the cranial and spinal ganglia (His W., 1868; Trainor et al., 2003). This cell population, which he named Zwischenstrang (the intermediate cord) was later referred to as the neural crest. Early grafting experiments in amphibians gave the first insights into the developmental potential of these cells (rev. Hörstadius S., 1950). Subsequently, lineage tracing experiments in avian embryos using various methods of marking the neural crest greatly enhanced our understanding of the pathways of migration and derivatives they formed. These initially involved radioactive labeling (Chibon, 1967; Weston, 1963), but were revolutionized by the advent of quail-chick chimeric grafts (Le Douarin, 1980), which allowed Le Douarin and colleagues to map neural crest migratory pathways, derivatives, and their axial level of origin (Le Douarin, 1973; Le Douarin and Teillet, 1974, 1973). Contribution of the neural crest towards the craniofacial architecture of vertebrates led to the genesis of the "new head hypothesis" (Gans and Northcutt, 1983), according to which, the possession of distinct craniofacial derivatives enabled diversification of the brain and acquisition of predatory behavior in vertebrates, as compared to filter feeding chordates (Le Douarin, 2004).

Abbreviations used in this paper: EMT, epithelial-to-mesenchymal transition; BMP, bone morphogenetic protein; FGF, fibroblast growth factor; NPB, neural plate border; RA, retinoic acid.

*Address correspondence to: Marianne M. Bronner. MC 139-74, 1200 East California Boulevard, Pasadena, CA - 91125, USA. Tel: +1 (626) 395-3355.
E-mail: mbronner@ caltech.edu - (iD http://orcid.org/0000-0003-4274-1862

Submitted: 24 January, 2018; Accepted: 24 January, 2018.

ISSN: Online 1696-3547, Print 0214-6282 
Their stem cell-like regenerative properties, long-range migratory capabilities, and experimental malleability make neural crest cells an excellent model system to study cell migration, developmental potential and cell-fate decisions (Dupin and Sommer, 2012; Smith, 1990; Tucker, 2004). Therefore, understanding how the neural crest develops can help us gain insights into how cells behave differently depending on their position and function in the organ-

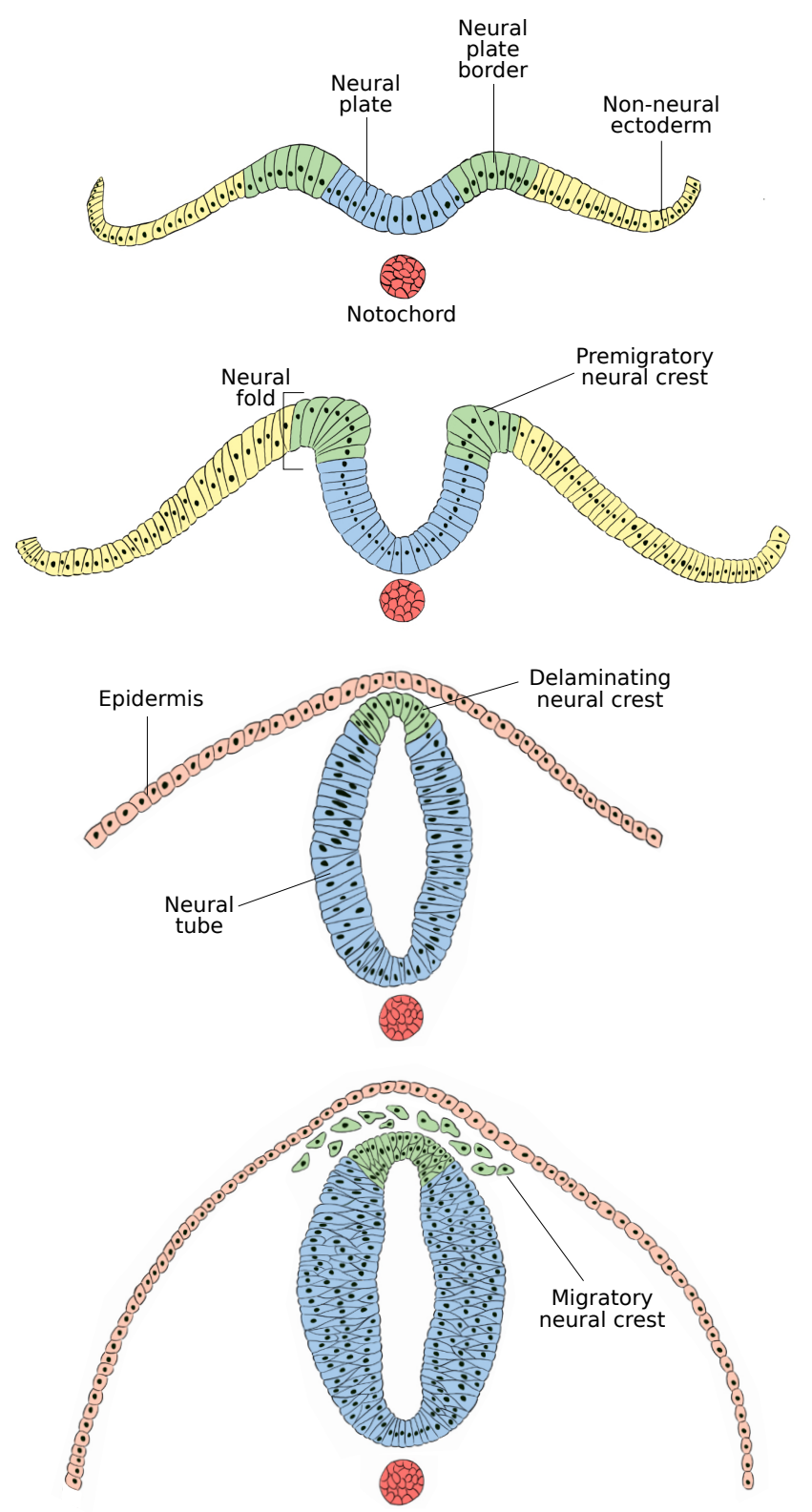

Fig. 1.The various stages of neural crest development. The neural crest is a transient population of multipotent cells found in vertebrates. Neural crest cells are specified at the border between the neural plate (blue) and non-neural ectoderm (yellow) at the gastrula stage. During neurulation, the neural plate border elevates to form the neural folds containing premigratory neural crest cells. As the neural folds fuse to form the neural tube, neural crest cells undergo an epithelial-to-mesenchymal transition (EMT), delaminate from the dorsal neural tube, and migrate extensively to various parts of the developing embryo where they differentiate into a plethora of derivatives. ism. The chick embryo has been a particularly valuable organism for addressing these questions. As an amniotic system, it shares similarity with humans at both the morphological and nucleotide level. In this review, we discuss mechanisms underlying neural crest specification, migration and differentiation, and the genetic toolbox available to study these biological processes in chick embryos.

\section{Induction of the neural crest in avian embryos}

Until the mid-2000s, the prevailing view of neural crest induction was that interactions between the non-neural surface ectoderm, neural plate, and/or underlying mesoderm resulted in specification of neural crest precursors via signaling interactions between tissues (Basch et al., 2004; Gammill and Bronner-Fraser, 2002; Monsoro-Burq et al., 2003; Takahashi et al., 2007). Moreover, multiple juxtaposition studies performed in both avian and amphibian embryos highlighted the role of the epidermis in specifying neural crest cells. However, most of the early experiments in chick embryos were performed after the neural tube had already formed. In 2006, Basch et al., presented a revised view on the specification and induction of the neural crest precursors (Basch et al., 2006). They hypothesized that regions of the epiblast were already induced to become presumptive neural crest during gastrulation, better matching experimental evidence in frog and zebrafish. The comparatively slow development of the chick embryo enabled more refined analysis of the timing of neural crest induction. By characterizing the expression level of the paired box transcription factor Pax7 in gastrulating chick embryos, Basch and colleagues concluded that the Neural Plate Border (NPB) region was already fated to become neural crest prior to completion of gastrulation, and that cells from this domain incorporate into the neural folds, and ultimately, the migratory neural crest. Dissection of the Pax7 expressing domain from the epiblast followed by explantation in a neutral environment was sufficient to give rise to migratory neural crest, identified by staining for the migratory cell-surface antigen HNK1. Finally, using molecular markers for mesoderm, they also demonstrated that the neural crest was specified without any interaction between the Pax7-expressing NPB and the underlying mesoderm. These results not only characterized Pax7 as an early NPB marker, but also placed the initiation of neural crest specification at or before gastrulation. More recently, Roellig and colleagues have expanded this viewpoint by resolving the co-expression pattern of transcription factors including Pax7, Sox2, and Six1 in the NPB at a single-cell level (Roellig et al., 2017).

The specification of neural crest cells has been described as a multistep process involving Fibroblast Growth Factor (FGF), Bone Morphogenetic Protein (BMP), and the Wnt signaling cascades, with additional contributions by Notch/Delta, Retinoic Acid (RA), Hedgehog, and endothelin signaling (Barembaum and BronnerFraser, 2005; Basch et al., 2004; Knecht and Bronner-Fraser, 2002; Steventon et al., 2009). Of these, FGF signaling, which arises from the surrounding mesoderm, acts in conjunction with Wnt signaling to repress BMP signaling during the first half of neural crest induction (Stuhlmiller and García-Castro, 2012). In the second half, inhibition of FGF signaling allows for the activation of BMP signaling, which together with Wnt signaling activates a pool of transcription factors referred to as NPB specifiers. These NPB specifiers, that include transcription factors Pax3/7, Msx1/2, Pax7, Zic1, Gbx2, and Tfap2, play an important role in establishing the interface 
between the neuroepithelium and the surface ectoderm (Grocott et al., 2012; Khudyakov and Bronner-Fraser, 2009). Once the NPB is established, the NPB specifier genes activate another set of transcription factors called the neural crest specifier genes, including FoxD3, Sox9, Snail, and Sox10 (Simões-Costa and Bronner, 2013, 2015; Simões-Costa et al., 2014). Of these, the transcription factor Forkhead Box protein D3 (FoxD3) appears to be expressed first and is required for the subsequent onset of other neural crest specifier genes (Labosky and Kaestner, 1998; Sasai et al., 2001; Sauka-Spengler and Bronner-Fraser, 2008; Stewart et al., 2006). It is expressed in both premigratory and some migratory neural crest cells, regulating their EMT and thereby controlling emigration (Fairchild etal., 2014; Kos et al., 2001). However, detailed genomic analysis has revealed that the expression of FoxD3 in the cranial versus the trunk axial level is tightly regulated by direct input from different transcription factors into two different enhancers, NC1 and NC2 (Simões-Costa et al., 2012). Interestingly, the NC1 enhancer governs the expression of FoxD3 in the premigratory cranial neural crest, while the NC2 enhancer is initially active in the trunk neural crest. In contrast, the neural crest specifier gene Sox10 is expressed as neural crest cells prepare to emigrate and then is maintained in the migratory population (Betancur et al., 2010). It also directly or indirectly regulates the activity of proteins like Rho GTPases that are actively involved in actin reorganization, thus contributing to cell membrane fluidity, and ultimately, cell migration (Liu and Jessell, 1998; Sit and Manser, 2011), as discussed in detail below. Later, Sox10 plays an important role in differentiation of neural crest cells into specific neuronal cell types (Carney et al., 2006; Kim et al., 2003).

Contrary to the induction model of neural crest specification, a recent study in Xenopus embryos has proposed that neural crest cells retain multipotency from an early blastula to the neurula stage (Buitrago-Delgado et al., 2015). Interestingly, this model seems consistent with findings in avian embryos, where expression of the earliest neural plate border marker, Pax7, was observed in distinct regions of epiblast between stages 3 and 4 (Basch et al., 2006).

\section{Neural crest migration pathways along the body axis of the chick embryo}

Following delamination from the dorsolateral part of the neural tube, neural crest cells undergo a change in their transcriptional landscape, assuming a state distinct from both the neural tube and the epidermis. This migratory state is marked by a reduction in cell-cell adhesion and enhanced interactions with the extracellular matrix. In chick embryos, the process of delamination overlaps with neural tube closure (Le Douarin and Kalcheim, 1999; Duband and Thiery, 1982; Théveneau et al., 2007), and differs along the rostral-caudal axis. In the rostral part of the embryo, the cranial neural crest cells undergo EMT as a collective event, resulting in the delamination of numerous cells concurrently. They then follow distinct streams and migrate extensively with leader cells pioneering the pathways followed by closely-associated follower cells. In contrast, trunk neural crest cells delaminate by leaving the neural tube one cell at a time in a drip-like fashion and start migrating immediately after detaching from the tube. Interestingly, neural crest migration in the trunk is tightly linked with differentiation of the somites (Sela-Donenfeld and Kalcheim, 1999). As neural crest cells first leave the neural tube, they migrate between the neural tube and the adjacent epithelial somite. The somites subsequently undergo an EMT to form the dermomyotomes and sclerotomes. At this point, trunk neural crest cells invade the sclerotomes and migrate throughout the anterior half of each, resulting in their segmental migration (Bronner-Fraser, 1986; Rickmann et al., 1985). In the chick, neural crest cells typically begin to delaminate about five somite lengths above the last formed somite. The caudal trunk neural crest delaminates almost a day after the completion of neurulation (Osorio et al., 2009).

Neural crest migration is a dynamic process. For example, the chick cranial neural crest cells emigrate from the dorsal neural tube immediately after its closure in a rostral-caudal wave, with cells at the midline of the caudal forebrain and midbrain emerging prior to those adjacent to the hindbrain. Not only are there differences in the migratory properties of cells originating from different axial levels, but the leader and trailer cells can also exhibit differences in migration rates and directionality. At the hindbrain level, these differences correlate with segmentation of the rhombomeres (Kulesa and Fraser, 1998, 2000; Kulesa and Gammill, 2010; Lumsden et al., 1991). Neural crest cells migrating towards branchial arch 1 and 3 exhibit collective cell migration with high directionality, where the leader cell moves at a speed similar to the cells following in the chain. In contrast, cells migrating into branchial arch 2 display more directed, individual cell movement with low cell-cell contacts, albeit at much slower migration speeds (Kulesa and Fraser, 2000). The neural crest cells that originate from rhombomeres 3 and 5 migrate from the dorsal midline of the neural tube, following a diagonal cellular trajectory in a caudo- or rostro-lateral manner before migrating laterally away from the neural tube, thus avoiding inhibitory environments immediately lateral to $\mathrm{r} 3$ and r5. Interestingly, these cells end up getting stalled as they reach the lateral-most extent of the neural tube. Eventually, they either merge with their neighboring stream from rhombomere 4 migrating towards the second branchial arch, or they remain stationary, suggesting that the microenvironment adjacent to $\mathrm{r} 3$ is inhibitory for neural crest migration, thus establishing a neural crest cell-free zone. However, cells that merge with their neighboring stream maintain filipodial contacts with the leader cells, allowing them to alter the direction of their migration towards the second branchial arch (Kulesa and Fraser, 1998, 2000).

Trunk neural crest migration is restricted to two major migratory pathways - ventral, and dorsolateral. In the chick, neural crest cells first migrate ventrally, since repressors such as Slit ligands, endothelin-3, and ephrinB1 are initially expressed along the dorsolateral pathway, thus restricting neural crest cells to follow a ventral migratory pathway and migrate through the inhibitor-free anterior part of the sclerotome (Harris and Erickson, 2007). The posterior sclerotome, on the other hand, expresses members of ephrin and semaphorin families, along with inhibitory Extracellular Matrix (ECM) molecules, Versicans, and F-spondin (Newgreen and Gooday, 1985; Newgreen et al., 1986). The underlying mechanism of repression arises from the interaction between the migratory neural crest receptors eph and neuropilin2 and their antagonistic ligands EphrinB and Semaphorin, respectively. Indeed, when neural crest cells from the trunk axial level were cultured in dishes containing fibronectin-coated matrices with alternating ephrin stripes, the cells moved along the regions with no ephrin, while completely avoiding ephrin coated stripes (Davy and Soriano, 2007; Krull et al., 1997; Wang and Anderson, 1997). Migration of 
these cells is also controlled temporally in a chemotactic fashion by the levels of Stromal cell-derived factor 1 (SDF1) along the ventro-dorsal axis (Kasemeier-Kulesa et al., 2010). Neural crest cells that differentiate within the sclerotome give rise to the dorsal root ganglia, with high levels of Notch leading to a glia fate, while high levels of Notch's ligand Delta lead to a neuronal fate. Expression of the chemokine ( $\mathrm{C}-\mathrm{X}-\mathrm{C}$ motif) receptor 4 drives the first wave of ventrally-migrating trunk neural crest cells towards the dorsal aorta (Saito et al., 2012). Cells that lack the expression of CXCR4 continue to migrate and give rise to sympathoadrenal cells that then condense to form sympathetic ganglia as well as the adrenal medulla. BMP signaling from the dorsal aorta influences these cells to become sympathoadrenal while interactions with presumptive adrenal cortical cells influence further differentiation into the adrenal medulla (Saito and Takahashi, 2015).

The second migratory pathway, the dorsolateral pathway, is followed by neural crest cells that are fate-restricted to become pigment cell progenitors in a FoxD3-dependent manner (Tosney, 2004). Low levels of FoxD3 allow proper regulation of MITF, a transcription factor necessary for the differentiation of neural crest cells into melanocytes (Thomas and Erickson, 2009). Once the pigment precursors are specified, ephrin mediates the increase in levels of its receptor, EphB2, on the surface of these cells, facilitating their migration through regions that initially inhibited the migration of multipotent trunk neural crest cells.

\section{Regionalization along the anterior-posterior axis}

Neural crest cells migrate long distances in response to both environmental cues and various signaling cascades (Kulesa and Gammill, 2010). Once they reach their final destination, the cells can differentiate into a wide array of cell types. The pioneering work of Le Douarin and colleagues showed that the neural crest can be categorized into four unique, albeit overlapping regions along the body axis in avian embryos, based on their axial level of origin (Fig. 2). The cranial neural crest, also known as the cephalic neural crest, includes the forebrain, midbrain and the anterior hindbrain region; the vagal neural crest spans from the posterior hindbrain region to

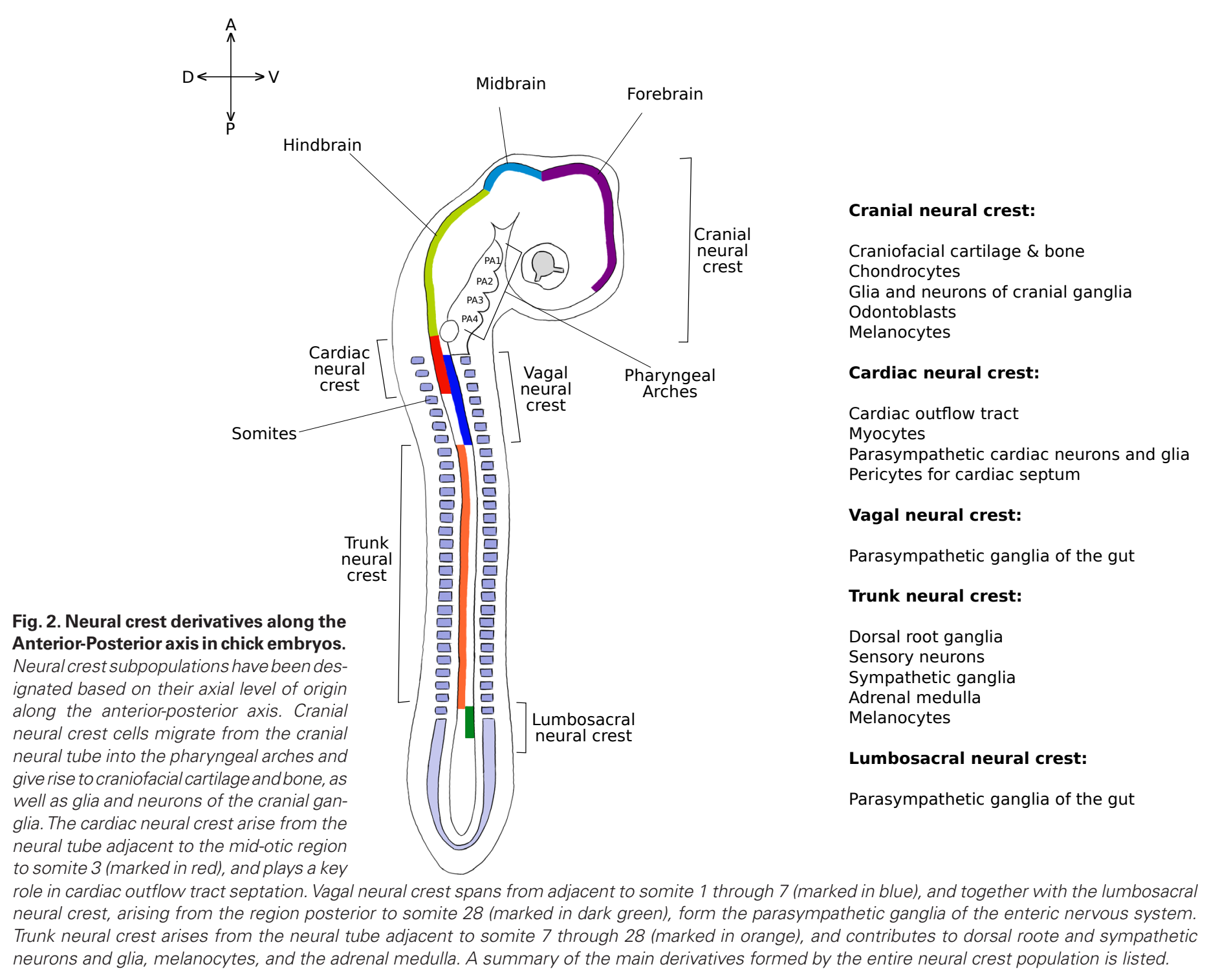


somite 7; the trunk neural crest comprises somite 8-28; and the lumbosacral neural crest represents the region posterior of somite 28. Within the vagal neural crest, there is another subpopulation called the cardiac neural crest that arises from the neural tube adjacent to the mid otic-placode to somite 3 . The cranial neural crest contributes to the craniofacial skeleton, and the glia and neurons of the cranial ganglia (D'amico-Martel and Noden, 1983; Le Douarin and Kalcheim, 1982). The vagal neural crest populates the gut, and the neurons and glia of the enteric nervous system. The cardiac neural crest gives rise to the cardiac outflow tract and the pharyngeal arches, and is the only neural crest subpopulation that contributes to proper cardiovascular development (Stoller and Epstein, 2005). The trunk neural crest cells form the dorsal root ganglia, sympathetic ganglia, and the adrenal medulla. Finally, the lumbosacral neural crest also contributes to the enteric nervous system. Interestingly, regardless of the axial identity, neural crest cells also differentiate into melanocytes, neurons, and glia (Le Douarin and Kalcheim, 1982).

Axial level differences in differentiative ability are highlighted by transplantation experiments performed in chick embryos, where cranial and trunk neural crest cells were exchanged. Cranial neural crest cells give rise to the craniofacial skeleton, and happens to be the only neural crest population capable of doing so. When these cells were transplanted to the trunk, they not only compensated for the absence of trunk neural crest cells, but also differentiated into cartilage nodules (Le Douarin and Teillet, 1974; Le Lievre et al., 1980). In contrast, trunk neural crest cells failed to give rise to any cartilage when transplanted to the cranial level, even though they contributed to the neurons and glia of the cranial ganglia (Nakamura and Ayer-le Lievre, 1982). Indeed, genomic analysis revealed that the endogenous levels of the neural crest specifier genes FoxD3 and Sox 10 are controlled by different set of enhancers at the cranial and trunk axial levels (Betancur et al., 2010, 2011; Simões-Costa et al., 2012). Not only that, the transcriptional inputs these enhancers receive from their upstream genes are also different at the two axial levels (Simões-Costa et al., 2012). Taken together, these results suggest that there are intrinsic differences between the developmental fate of the two populations.

Recently, it has been possible to "reprogram" neural crest axial identity by tweaking the underlying genetic circuitry. Simões-Costa and Bronner revealed a cranial crest-specific sub-circuit by performing transcriptional profiling of the migratory crest from the cranial and trunk axial levels (Simões-Costa and Bronner, 2016). They discovered that ectopic expression of a subset of this sub-circuit in the trunk, namely the transcription factors Sox8, Tfap2b, and Ets1, was sufficient to alter the fate and identity of trunk neural crest into 'cranial-like' cells. The altered identity was assessed by testing the ability of the trunk neural crest cells to activate Sox10e2, an enhancer that governs the expression of Sox10 selectively in the migratory cranial neural crest cells (Betancur et al., 2010). To investigate the effect on trunkneural crest cell fate, they transplanted cells expressing the three factors from GFP donor embryos into wild-type chick embryos. Following incubation until embryonic day 7 , they observed that cells transfected with the cranial neural crest-specific sub-circuit had successfully differentiated into chondrocytes. The control group, on the other hand, did not form any part of the cartilage, suggesting that expression of the three transcription factors was sufficient to drive the population of the trunk neural crest towards a craniofacial derivative fate.

\section{Multipotent or fate-restricted?}

The advent of vertebrates has been suggested to overlap with the appearance of two cell types, neural crest cells and ectodermal placodal cells (Gans and Northcutt, 1983; Gee, 1996; Glenn Northcutt, 2005), which contribute to the facial skeleton, cranial ganglia and sense organs. As the craniofacial skeleton and peripheral nervous system of the head are defining features of vertebrates, this suggests that the ability of neural crest cells to differentiate into a multitude of cell types played an important role in the evolution of vertebrates. This raises the intriguing question - how are neural crest cells able to differentiate into such diverse cell types? Over the last several decades, many hypotheses have been formulated to address this question.

Multiple studies performed over the last three decades support the idea that the neural crest is a multipotent population with the ability to give rise to many or all potential derivatives. The first piece of evidence in vivo came from Bronner-Fraser and Fraser when they injected fluorescent Dextran molecules into individual trunk and cranial neural crest cells before their delamination and migration (Bronner-Fraser and Fraser, 1989, 1988). They observed that the progeny of the injected cells were capable of differentiating into several cell types such as sensory neurons, Schwann cells, and melanocytes, thus suggesting that a part of the migratory trunk neural crest was multipotent. They also reported the possibility of a common precursor for both the Central Nervous System (neural tube) and the Peripheral Nervous System (neural crest). Around the same time, Baroffio and colleagues successfully cultured cranial neural crest cells obtained from quail embryos and reported that the cells exhibited a wide developmental potential, corroborating the in vivo results obtained by Bronner-Fraser and Fraser (Baroffio et al., 1988). In addition, other clonogenic culture studies of neural crest cells reported that their lineage decision was directly influenced by the growth factors used in the culture medium (Lahav et al., 1998).

On the other hand, there is some evidence suggesting that the neural crest may be a heterogeneous mixture of fate-restricted cells. For example, Nitzan and colleagues have proposed that premigratory neural crest cells are unipotent and arranged in the dorsal neural tube in a spatio-temporal pattern in chick embryos that correlates with the derivatives they will form (Nitzan et al., 2013).

It is important to note that the techniques used in the abovementioned studies suffered from some major drawbacks. First, in vivo lineage tracing experiments using fluorescent Dextran only allowed for the characterization of neural crest derivatives based on visualization of a lineage marker that is transient and diluted with each cell division. Second, clonal analysis in vitro requires growing cells in a culture medium outside the context of the developing embryo. However, Baggiolini and colleagues used a confetti mouse model to trace neural crest cells and their derivatives in vivo, allowing them to achieve permanent lineage labeling at single-cell resolution and in an intact endogenous environment of the embryo (Baggiolini et al., 2015). Using this model, they traced nearly 100 neural crest cells, both premigratory and migratory, and demonstrated that almost $75 \%$ of these cells gave rise to multiple derivatives comprised of the dorsal root ganglia, melanocytes, sympathetic ganglia, and Schwann cells. While they observed that a small proportion of the cells gave rise to a single derivative, the vast majority of the trunk neural crest cells were multipotent, suggesting that the neural crest is primarily a multipotent popula- 
tion and thereby confirming the work in chick embryos done by Bronner-Fraser and Fraser some 25 years earlier.

\section{Experimental strategies to study neural crest development}

Some of the earliest experiments performed in developmental biology relied on ablation and grafting experiments to decrypt the puzzle that was the developing embryo. After Wilhelm Roux first published his ablation technique, Hans Spemann used it to investigate the role of tissue interactions in eye development. At the time, the process of lens formation was not thoroughly understood. By destroying the optic vesicle before it associated with the overlying ectoderm, Spemann demonstrated the importance of the interactions between the optic vesicle and the ectoderm in inducing proper lens development.

In the $20^{\text {th }}$ century, the ablation technique was adapted to the chick embryo to address a diverse array of questions. It was through the ablation of the cardiac neural crest that the contribution of this population of neural crest cells to proper cardiovascular development was highlighted (Besson et al., 1986; Kirby and Waldo, 1995; Kirby et al., 1985; Nishibatake et al., 1987). However, these experiments only revealed some of the developmental capabilities of the neural crest tissue. Moreover, it was difficult to conclude whether the presence or absence of structures after neural crest ablation indicated their site of origin. However, technical breakthroughs in biology have made it possible to address such questions in much finer detail. Here, we discuss some of the experimental techniques that are currently available to study neural crest development in chick embryos.

\section{Neural crest lineage tracing}

One of the biggest technical challenges in neural crest biology was the ability to distinguish a neural crest cell from its neighbors while it migrated through mesenchymal regions in the embryo. As a result, cell marking techniques that would allow investigators to trace individual cells were highly sought after. Radioactive labeling of nuclei with tritiated thymidine followed by transplantation of labeled tissue in a host embryo allowed Weston (1963) and Chibon (1967) to follow migration of these cells in avian and amphibian embryos, respectively (Chibon, 1967; Weston, 1963). The technique was soon adapted in a number of studies (Johnston, 1966; Noden, 1975, 1978; Weston and Butler, 1966). However, the levels of tritiated thymidine diluted with each cell division event, making this technique appropriate for only short-term tracing of neural crest cells. Moreover, the method was also prone to giving false labeling of non-neural crest cells, as the radioactive label from a dead cell could spread to its neighbors. Therefore, it was important to look for alternative strategies for neural crest labeling.

In the 1960s, Le Douarin devised the elegant quail-chick chimeras as a method to label cells and follow the long-term fate of neural crest cells, allowing her to trace neural crest pathways of migration and characterize their numerous derivatives (Le Douarin, 1969, 1973). This technique was based on the difference in the heterochromatin state of chick and quail embryos, which could be labeled with a simple histological Feulgen stain. These experiments not only made it possible to follow the migratory pathways of these cells throughout the embryo, but also provided valuable insights into the extensive nature of neural crest derivatives. Using this approach, Douarin categorized the derivatives of the neural crest at different axial levels in chick embryos, leading to important observations regarding differences in properties of neural crest cells derived from different axial levels.

To confirm these results using methods that did not require interspecies transplantation, the next generation of labeling methods made use of fluorescently labeled large molecules such as Lysinated Rhodamine Dextran (LRD) and vital dyes such as Dil (1,1'-dioctadecyl-3,3,3',3'-tetramethylindocarbocyamide perchlorate). While these labeling methods were still transient, they offered several advantages over radioactive labeling. For example, both LRD and Dil were not prone to leak, hence reducing false labeling of tissues surrounding neural crest cells. They both were transferred to their daughter cells for a few generations, allowing tracking of migration at single cell resolution, albeit for short intervals. Most importantly, using these dyes to label cells and track their migration within the same embryo circumvented the need for grafting labeled cells in a host embryo, making their application much simpler than their predecessors. These techniques were instrumental in demonstrating the multipotent nature of neural crest cells not only in avian embryos (Artinger et al., 1995; Bronner-Fraser and Fraser, 1989, 1988; Lumsden et al., 1991; Serbedzija et al., 1989, 1990), but also in mammalian systems (Osumi-Yamashita et al., 1996). These labeling techniques gave valuable insights into the developmental potential of neural crest cells. However, given their transient nature, it was not possible to trace a single neural crest cell to the tissue to which it contributed later on during development. Hence, it was necessary to establish techniques that would not only allow labeling of single cells, but would also ensure long-range tracking of their migratory pathway.

With their ability to generate double-stranded DNA that stably integrates into the host cell genome, retroviruses offer an easy and effective alternative to classical cell labeling techniques described above. Replication Competent and IncompetentAvian Retroviruses (RCAS/RIA) have long been used to permanently label single cells and their progeny by expressing reporter genes through the viral promoter (Frank and Sanes, 1991; Murai et al., 2015; Price et al., 1987; Sanes, 1989; Sanes et al., 1986). Injecting the viruses at different developmental stages at precise locations in the embryo allows spatiotemporal control over the labeling of neural crest cells at different axial levels. Pseuodotyping the virus envelop protein ensures that the infection is limited to chicken cells. Moreover, these viruses have also been used to misexpress endogenous genes in neural crest cells (Eames et al., 2004).

\section{Crestospheres}

Methods employing in vitro culturing of neural crest cells were already established in the 1970s. However, it wasn't possible until very recently to successfully culture premigratory neural crest cells in their multipotent and self-renewal state (Cohen and Konigsberg, 1975). After they migrate from the neural tube, neural crest cells have a limited ability to self-renew for a few cell cycles (Stemple and Anderson, 1992; Trentin et al., 2004), and thus rapidly transition from stem cells to progenitor cells. However, more recently, Kerosuo and colleagues have successfully optimized conditions to culture premigratory neural crest cells as "crestospheres," enabling long term self-renewal and retention of multipotency of the premigratory neural crest cells (Kerosuo et al., 2015).

Premigratory neural crest cells express a suite of neural crest 
specifiergenes including FoxD3, Sox9, Snail2, and Sox10 (SimõesCosta and Bronner, 2015; Simões-Costa et al., 2014). Kerosuo and colleagues tested various culture conditions that not only enabled proper expression of these transcription factors, but also promoted the maintenance of their self-renewal properties and stemness (Kerosuo et al., 2015). Using a cocktail of growth factors that included epidermal growth factor, basic FGF, and RA, they found optimal conditions to culture premigratory neural crest cells in their multipotent state, as judged by the expression of neural crest marker genes in the cultured crestospheres. Interestingly, this medium also enabled culturing of crestospheres from entire neural tube tissue, suggesting that the correct proportion of growth factors supported culturing of neural crest at the cost of neural fate. Using these conditions, they successfully maintained crestosphere cultures for as long as 5 weeks, albeit at a declining proliferation rate. By exposing them to specific differentiation media, Kerusuo and colleagues also demonstrated the differentiation potential of crestospheres into multiple neural crest derivatives.

Taken together, this technique of in vitro culturing of premigratory neural crest cells offers an interesting model to study neural crest development. Not only can the crestospheres be used to answer questions about the stem cell-like behavior of neural crest cells, but they can also be used to investigate the role of certain environmental cues in cell migration and differentiation. By culturing crestospheres from GFP transgenic chick embryos and transplanting them back into wild type embryos, one could study the developmental potential of neural crest cells at singlecell resolution.

\section{Antisense morpholinos}

The concept of using antisense oligonucleotides to study gene expression was first proposed almost 20 years ago (Baker and Monia, 1999; Crooke, 1999). The antisense technology relied on the understanding of nucleic acid structure and the underlying mechanisms governing their hybridization. Synthetic oligonucleotides designed following these principles were capable of inhibiting protein translation via three different pathways: first, by disrupting ribosome assembly at the targeted mRNA; second, by blocking splice junctions through direct hindrance; third, by recruiting RNase $\mathrm{H}$ enzymes that degrade the target mRNA through recognition of the synthetic oligonucleotide-mRNA duplex. While the specificity of these oligonucleotides was a cause for concern, subsequent structural and chemical modifications of the oligonucleotides made this a useful technique for knockdown studies in different model systems including Xenopus (Heasman et al., 2000), zebrafish (Nasevicius and Ekker, 2000; Yang et al., 2001), and sea urchins (Howard et al., 2001).

Antisense morpholino oligonucleotides were first implemented in avian embryos for gene knockdowns when Kos and colleagues demonstrated the role of FoxD3 in maintaining the neural crestderived melanoblast lineage (Kos et al., 2001). Since then, the entire chick neural crest community has relied on morpholinos to interrogate the role of different genes in neural crest development (Barembaum and Bronner, 2013; Basch et al., 2006; Betancur et al., 2010; Simões-Costa et al., 2015, 2012). Important controls for establishing specificity of morpholinos include rescue experiments and validating protein knock-down. However, given the disadvantages of using morpholinos, including rising concerns about non-specific effects (Gerety and Wilkinson, 2011), cost ineffectiveness, and inability to target non-coding regions, the community has turned to CRISPR/Cas9 technology for more robust gene knockouts.

\section{CRISPR/Cas9-mediated genome editing}

Less than a decade ago, genome editing approaches were limited to arbitrary mutations incorporated as a result of Non-Homologous End Joining (NHEJ) repair mechanism or Homologous Recombination by using a donor plasmid containing the insert fragment. Specificity of the DNA binding domain found in transcription factors led to the discovery of DNA nucleases, proteins capable of inducing site-specific mutagenesis. Zinc Finger Nucleases (ZFNs) and Transcription Activator-Like Effector Nucleases (TALENs) were used extensively in a variety of animal models (Beerli and Barbas, 2002; Beerli et al., 2000; Zhang et al., 2011). However, the chick community relied on anti-sense morpholinos (Corey and Abrams, 2001) and dominant-negative constructs for transient knockdown of genes of interest. Even though the efficiency of these techniques has been documented, expensive and tedious cloning procedures for DNA nucleases, and non-specific effects for morpholinos and dominant negative proteins limited the applications of these techniques (Eisen and Smith, 2008; Joung and Sander, 2013; Schulte-Merker and Stainier, 2014).

The discovery of CRISPR (Clustered Regularly Interspaced Short Palindromic Repeats)-Cas9 has ushered in a new era of molecular genetics and has allowed researchers to interrogate the role of specific genes in development of an organism. CRISPR-Cas is an important part of the prokaryotic immune response (Bhaya et al., 2011; Wiedenheft et al., 2012) and has now been harnessed for targeted genome editing in a variety of model systems (Cong et al., 2013; Dickinson et al., 2013; Ren et al., 2014; Stolfi et al., 2014). Mechanistically, a short RNA sequence, known as guide RNA (gRNA), guides a Streptococcus pyogenes-derived endonuclease Cas9 to specific target sites on the genome. The binding of the Cas9-gRNA complex is a two-step process: first, Cas9 identifies a Protospacer Adjacent Motif (PAM) of the form "NGG" on the genomic DNA; second, the protospacer domain within the gRNA forms Watson-Crick base pairing with the target. Once bound, Cas9 induces a double stranded break 3-4 base pairs upstream of the PAM (Jinek et al., 2012; Mali et al., 2013a). The CRISPR system has been widely used for knocking out genes (Cong et al., 2013; Jiang et al., 2013; Jinek et al., 2013; Mali et al., 2013a; Shalem et al., 2015; Wang et al., 2014), and knocking in short oligonucleotides and fragments of interest (Cong et al., 2013; Dickinson et al., 2013). A catalytically de-active variant (dCas9), with mutated nuclease sites, has also been used to regulate expression of specific genes using fused activation (e.g. VP16) and repression (e.g. KRAB) domains (Cheng et al., 2013; Gilbert et al., 2013; Maeder et al., 2013; Mali et al., 2013b; Perez-Pinera et al., 2013; Qi et al., 2013).

We and others have recently optimized the CRISPR/Cas9 system for genome editing in chicken embryos using a three-fold optimization strategy (Gandhi et al., 2017b; Williams et al., 2018). First, using an in-situ hybridization and quantitative Reverse Transcription PCR (qRT-PCR)-based assay, we demonstrated that a much higher level of gRNA transcription can be achieved using a chicken-specific U6 compared to its human counterpart (Kudo and Sutou, 2005; Wise et al., 2007). Second, following strategies proposed by Chen and colleagues (Chen et al., 2013), we implemented the ' $\mathrm{F}+\mathrm{E}$ ' ('F'-flip, 'E'-extension) modification in the gRNA 
scaffold to avoid premature termination of gRNA transcription and account for stable Cas9-gRNA iinteraction. We also flanked Cas9 with two nuclear localization signal sequences to ensure complete compartmentalization of Cas9 protein in the nucleus (Chen et al., 2013; Stolfi et al., 2014). Using previously described principles (Gandhi et al., 2017; Moreno-Mateos et al., 2015), we designed gRNAs targeting Pax7 and Sox10 in the neural crest (Fig. 3). By simple electroporation of the Cas9 and gRNA constructs in gastrulating stage $\mathrm{HH} 4$ (Hamburger and Hamilton, 1951) embryos, we validated the role of Pax7 and Sox10 in specification and migration of neural crest cells, respectively (Basch et al., 2006; Betancur et al., 2010). Our optimized system also allowed us to interrogate the nodes of a small neural crest-specific sub-circuit where Pax7 has been shown to regulate the activity of FoxD3 and Ets1, while having an indirect effect on the expression of Sox10 (SimõesCosta and Bronner, 2015). Finally, we demonstrated that Pax7 regulates endogenous levels of FoxD3 in the cranial neural crest cells through direction transcriptional input into the FoxD3-NC1 enhancer (Simões-Costa et al., 2012).

Successful implementation of the CRISPR/Cas9 system in chick embryos has opened the doors to understanding neural crest development at a much more detailed level. It is now possible to investigate complex gene regulatory interactions underlying different neural crest developmental modules. For genes that are expressed in different cells at various timepoints during development, it is now possible to target them in a tissue-specific manner and interrogate their function in particular cell lineages. Finally, since CRISPR-Cas9 targets the genome directly, targeting non-coding regions in the genome can help identify putative enhancers that govern the expression of different genes in the neural crest. For example, the expression of both FoxD3 and Sox10 is regulated by two different enhancers in cranial and trunk neural crest cells, respectively (Betancur et al., 2010; Simões-Costa et al., 2012). Hence, it is now possible to probe the role of cis-regulatory elements in regulating the spatio-temporal pattern of neural crest genes. Moreover, by fusing gRNAs with epigenetic modification enzymes such as histone acetyl-transferases, demethylases, etc., the CRISPR-Cas9 system can also be used to decipher epigenetic mechanisms of transcriptional regulation of target genes (Hilton et al., 2015).

\section{Concluding remarks}

In this review, we have summarized aspects of the history of neural crest studies in avian embryos and fundamental principles underlying neural crest development. The neural crest is a stem cell-like population of cells that is responsible for the emergence of craniofacial cartilage and bones in vertebrates, effectively parting them from invertebrate chordates. Through a network of transcription factors and signaling cascades, different segments of neural crest development are tightly regulated. While many neural crest cells are multipotent, it remains possible that some neural crest cells may be fate restricted at early stages. However, lineage experiments in chicks (Bronner-Fraser and Fraser, 1988) are highly concordant with recent work in mice by Baggiolini and colleagues in 2015. Using a genetically labeled confetti mouse model, Baggiolini and colleagues performed lineage tracing on premigratory neural crest cells and demonstrated that most of the cells are multipotent and hence are capable of differentiating into a diverse array of derivatives (Baggiolini et al., 2015).

An up-to-date version of the gene regulatory network underlying different modules of neural crest development, such as induction, specification, migration, and differentiation has been described by Martik and Bronner (2017). While we currently have a description of direct or indirect interactions between different neural crest transcription factors, several questions remain unanswered. For example, multiple mechanistic studies looking into these genetic interactions have posed questions about how non-coding RNAs such as IncRNAs, miRNAs, or piRNAs fit into the neural crest development paradigm. The answers to these questions will not only allow for the expansion of the neural crest gene regulatory network, but will also increase its resolution.

We have also highlighted some of the most common experimental techniques that have been used to unfold the mystery of neural crest development. More recently, high-throughput sequencing paired with classical perturbation techniques has greatly enhanced our knowledge of how the neural crest develops. Technologies such as ATAC-seq, ChIP-seq, single cell RNA-seq, CRISPR/Cas9, and high-resolution microscopy have opened up the possibilities to dig deeper into some of the fundamental questions in neural crest biology, for example what triggers the cell-fate decision at the
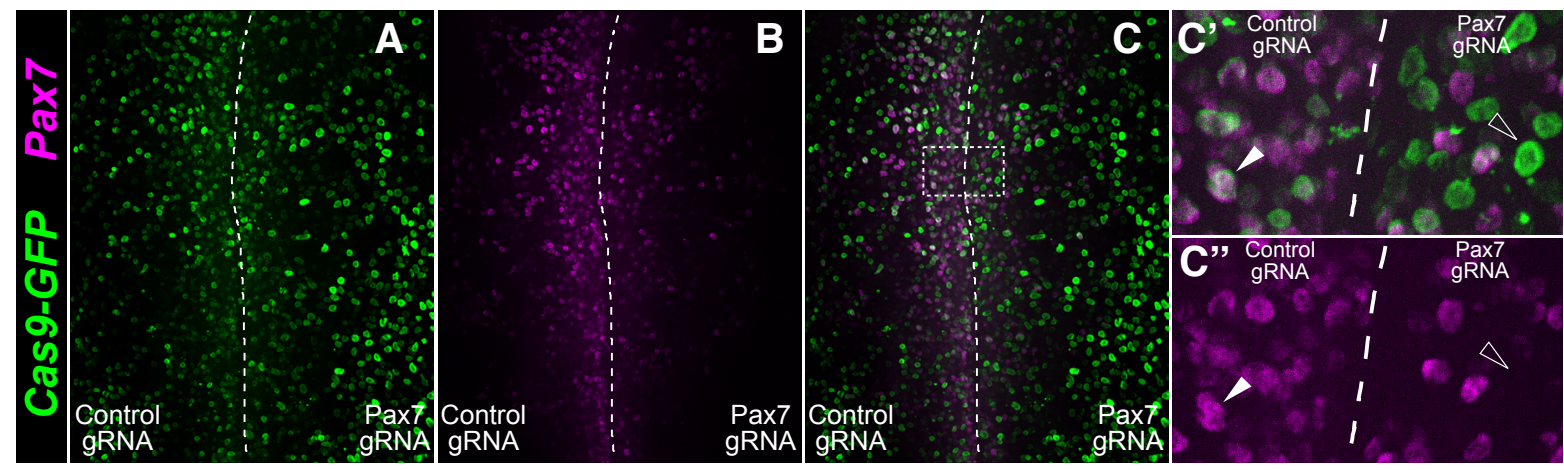

Fig. 3. CRISPR/Cas9-mediated knockout of Pax7 in chick embryos. (A) Gastrulating HH4 chick embryos were electroporated with U6.3>Control. gRNA.f+e on the left side and U6.3>Pax7.1.gRNA.f+e on the right side along with pCAGG>nls-Cas9-nls-GFP on both sides, and cultured ex ovo until stage HH9. (B,C) Immunostaining against Pax7 revealed substantial decrease in Pax7 protein level on the side electroporated with U6.3>Pax7.1.gRNA. $\mathrm{f}+\mathrm{e}$ compared to the control side. ( $\left.\mathbf{C}^{\prime}-\mathbf{C}^{\prime \prime}\right)$ Cells that were successfully transfected (Cas9-GFP') lost Pax7 on the right side but retained the protein on the control side, demonstrating the efficiency of the CRISPR/Cas9 system in knocking out genes in chick embryos. Dotted line represents midline of the embryo (from Gandhi et al., 2017b). 
neural plate border? What mechanistic differences govern collective versus individual cell migration of the neural crest? Are there molecular signatures that govern neural crest migration across different species? What triggers the compensatory response of neural crest cells? Can their stem cell-like properties play a role in tissue replacement therapy? With 150 years of neural crest research behind us and exciting emerging technologies in front of us, the next century promises to help unravel the answers to these enduring questions.

\section{References}

ARTINGER, K.B., FRASER, S., and BRONNER-FRASER, M. (1995). Dorsal and Ventral Cell Types Can Arise from Common Neural Tube Progenitors. Dev Biol 172: 591-601.

BAGGIOLINI, A., VARUM, S., MATEOS, J.M., BETTOSINI, D., JOHN, N., BONALLI, M., ZIEGLER, U., DIMOU, L., CLEVERS, H., FURRER, R., and SOMMER, L. (2015). Premigratory and Migratory Neural Crest Cells Are Multipotent In Vivo. Cell Stem Cell 16: 314-322.

BAKER, B.F., and MONIA, B.P. (1999). Novel mechanisms for antisense-mediated regulation of gene expression. Biochim Biophys Acta 1489: 3-18.

BAREMBAUM, M., and BRONNER-FRASER, M. (2005). Early steps in neural crest specification. Semin. Cell Dev Biol 16: 642-646.

BAREMBAUM, M., and BRONNER, M.E. (2013). Identification and dissection of a key enhancer mediating cranial neural crest specific expression of transcription factor, Ets-1. Dev Biol 382: 567-575.

BAROFFIO, A., DUPIN, E., and LE DOUARIN, N.M. (1988). Clone-Forming Ability and Differentiation Potential of Migratory Neural Crest Cells. Proc Natl Acad Sci. USA 85: 5325-5329.

BASCH, M.L., GARCÍA-CASTRO, M.I., and BRONNER-FRASER, M. (2004). Molecular mechanisms of neural crest induction. Birth Defects Res C Embryo Today 72: 109-123.

BASCH, M.L., BRONNER-FRASER, M., and GARCÍA-CASTRO, M.I. (2006). Specification of the neural crest occurs during gastrulation and requires Pax7. Nature 441: 218-222.

BEERLI, R.R., and BARBAS, C.F. (2002). Engineering polydactyl zinc-finger transcription factors. Nat Biotechnol 20: 135-141.

BEERLI, R.R., SCHOPFER, U., DREIER, B., and BARBAS, C.F. (2000). Chemically Regulated Zinc Finger Transcription Factors. J Biol Chem 275: 32617-32627.

BESSON, W.T., KIRBY, M.L., VAN MIEROP, L.H., and TEABEAUT, J.R. (1986). Effects of the size of lesions of the cardiac neural crest at various embryonic ages on incidence and type of cardiac defects. Circulation 73: 360-364.

BETANCUR, P., BRONNER-FRASER, M., and SAUKA-SPENGLER, T. (2010). Genomic code for Sox 10 activation reveals a key regulatory enhancer for cranial neural crest. Proc Natl Acad Sci USA 107, 3570-3575.

BETANCUR, P., SAUKA-SPENGLER, T., and BRONNER, M.E. (2011). A Sox10 enhancer element common to the otic placode and neural crest is activated by tissue-specific paralogs. Development 138: 3689-3698.

BHAYA, D., DAVISON, M., and BARRANGOU, R. (2011). CRISPR-Cas systems in bacteria and archaea: versatile small RNAs for adaptive defense and regulation. Annu Rev Genet 45: 273-297.

BRONNER, M.E., and SIMÕES-COSTA, M. (2016). The Neural Crest Migrating into the Twenty-First Century. Curr Top Dev Biol 115-134.

BRONNER-FRASER, M. (1986). Analysis of the early stages of trunk neural crest migration in avian embryos using monoclonal antibody HNK-1. DevBio/115:44-55.

BRONNER-FRASER, M., and FRASER, S. (1989). Developmental potential of avian trunk neural crest cells in situ. Neuron 3: 755-766.

BRONNER-FRASER, M., and FRASER, S.E. (1988). Cell lineage analysis reveals multipotency of some avian neural crest cells. Nature 335: 161-164.

BUITRAGO-DELGADO, E., NORDIN, K., RAO, A., GEARY, L., and LABONNE, C. (2015). Shared regulatory programs suggest retention of blastula-stage potential in neural crest cells. Science 348: 1332-1335

CARNEY, T.J., DUTTON, K. A, GREENHILL, E., DELFINO-MACHÍN, M., DUFOURCQ, P., BLADER, P., and KELSH, R.N. (2006). A direct role for Sox10 in specification of neural crest-derived sensory neurons. Development 133: 4619-4630.

CHEN, B., GILBERT, L.A., CIMINI, B.A., SCHNITZBAUER, J., ZHANG, W., LI, G.W., PARK, J., BLACKBURN, E.H., WEISSMAN, J.S., QI, L.S., HUANG, B. (2013). Dynamic imaging of genomic loci in living human cells by an optimized CRISPR/ Cas system. Cell 155: 1479-1491.

CHENG, A.W., WANG, H., YANG, H., SHI, L., KATZ, Y., THEUNISSEN, T.W., RANGARAJAN, S., SHIVALILA, C.S., DADON, D.B., and JAENISCH, R. (2013). Multiplexed activation of endogenous genes by CRISPR-on, an RNA-guided transcriptional activator system. Cell Res 23: 1163-1171.

CHIBON, P.P. (1967). Marquage nucléaire par la thymidine tritiée des dérivés de la crête neurale chez l'Amphibien Urodèle Pleurodeles waltlii Michah. Development 18: 343-358.

COHEN, A.M., and KONIGSBERG, I.R. (1975). A clonal approach to the problem of neural crest determination. Dev Biol 46: 262-280.

CONG, L., RAN, F.A., COX, D., LIN, S., BARRETTO, R., HABIB, N., HSU, P.D., WU, X., JIANG, W., MARRAFFINI, L.A., ZHANG, F. (2013). Multiplex Genome Engineering Using CRISPR/Cas System. Science 339: 819-823.

COREY, D.R., and ABRAMS, J.M. (2001). Morpholino antisense oligonucleotides: tools for investigating vertebrate development. Genome Biol 2: 1015.1-1015.3.

CROOKE, S.T. (1999). Molecular mechanisms of action of antisense drugs. Biochim Biophys Acta - Gene Struct Expr 1489: 31-43.

D'AMICO-MARTEL, A., and NODEN, D.M. (1983). Contributions of placodal and neural crest cells to avian cranial peripheral ganglia. Am J Anat 166: 445-468.

DAVY, A., and SORIANO, P. (2007). Ephrin-B2 forward signaling regulates somite patterning and neural crest cell development. Dev Biol 304: 182-193.

DICKINSON, D.J., WARD, J.D., REINER, D.J., and GOLDSTEIN, B. (2013). Engineering the Caenorhabditis elegans genome using Cas9-triggered homologous recombination. Nat Methods 10: 1028-1034.

LE DOUARIN, N.M. (1969). Details of the interphase nucleus in Japanese quail (Coturnix coturnix japonica). Bull Biol Fr Belg 103: 435-452.

LE DOUARIN, N.M. (1973). A biological cell labeling technique and its use in experimental embryology. Dev Biol 30: 217-222.

LE DOUARIN, N.M. (1980). The ontogeny of the neural crest in avian embryo chimaeras. Nature 286: 663-669.

LE DOUARIN, N.M. (2004). The avian embryo as a model to study the development of the neural crest: A long and still ongoing story. Mech Dev 121: 1089-1102.

LEDOUARIN, N.M. (1982). The Neural Crest. Cambridge University Press; Cambridge.

LE DOUARIN, N.M., and KALCHEIM, C. (1999). The neural crest (Cambridge University Press).

LE DOUARIN, N.M., and TEILLET, M.A. (1971). Localization, by the method of interspecific grafts of the neural area from which adrenal cells arise in the bird embryo. C R Acad Sci Hebd Seances Acad Sci D 272: 481-484.

LE DOUARIN, N.M., and DUPIN, E. (2014). The Neural Crest, a Fourth Germ Layer of the Vertebrate Embryo: Significance in Chordate Evolution. In Neural Crest Cells: Evolution, Development and Disease. Academic Press, pp. 3-26.

LE DOUARIN, N.M., and TEILLET, M.A. (1974). Experimental analysis of the migration and differentiation of neuroblasts of the autonomic nervous system and of neurectodermal mesenchymal derivatives, using a biological cell marking technique. Dev Biol 41: 162-184.

LE DOUARIN, N.M., and TEILLET, M.A. (1973). The migration of neural crest cells to the wall of the digestive tract in avian embryo. J Embryol Exp Morpho/30: 31-48.

DUBAND, J.L., and THIERY, J.P. (1982). Distribution of fibronectin in the early phase of avian cephalic neural crest cell migration. Dev Biol 93: 308-323.

DUPIN, E., and SOMMER, L. (2012). Neural crest progenitors and stem cells: From early development to adulthood. Dev Biol 366: 83-95.

DUPIN, E., CREUZET, S., and LE DOUARIN, N.M. (2006). The Contribution of the Neural Crest to the Vertebrate Body. In Advances in Experimental Medicine and Biology. Adv Exp Med Biol 589: 96-119.

EAMES, B.F., SHARPE, P.T., and HELMS, J.A. (2004). Hierarchy revealed in the specification of three skeletal fates by Sox9 and Runx2. Dev Biol 274: 188-200.

EISEN, J.S., and SMITH, J.C. (2008). Controlling morpholino experiments: don't stop making antisense. Development 135: 1735-1743.

FAIRCHILD, C.L., CONWAY, J.P., SCHIFFMACHER, A.T., TANEYHILL, L.A., and GAMMILL, L.S. (2014). FoxD3 regulates cranial neural crest EMT via downregula- 
tion of tetraspanin18 independent of its functions during neural crest formation. Mech Dev 132: 1-12.

FRANK, E., and SANES, J.R. (1991). Lineage of neurons and glia in chick dorsal root ganglia: analysis in vivo with a recombinant retrovirus. Development 111: 895-908.

GAMMILL, L.S., and BRONNER-FRASER, M. (2002). Genomic analysis of neural crest induction. Development 129, 5731-5741.

GANDHI, S., HAEUSSLER, M., RAZY-KRAJKA, F., CHRISTIAEN, L., and STOLFI, A. (2017). Evaluation and rational design of guide RNAs for efficient CRISPR/ Cas9-mediated mutagenesis in Ciona. Dev Biol 425, 8-20.

GANDHI, S., PIACENTINO, M.L., VIECELI, F.M., BRONNER, M.E. (2017b). Optimization of CRISPR/Cas9 genome editing for loss-of-function in the early chick embryo. Dev Biol 432: 86-97.

GANS, C., and NORTHCUTT, R.G. (1983). Neural crest and the origin of vertebrates: a new head. Science 220: 268-273.

GEE, H. (1996). Before the backbone : views on the origin of the vertebrates (Chapman \& Hall).

GERETY, S.S., and WILKINSON, D.G. (2011). Morpholino artifacts provide pitfalls and reveal a novel role for pro-apoptotic genes in hindbrain boundary development. Dev Biol 350, 279-289.

GILBERT, L.A., LARSON, M.H., MORSUT, L., LIU, Z., BRAR, G.A., TORRES, S.E., STERN-GINOSSAR, N., BRANDMAN, O., WHITEHEAD, E.H., DOUDNA, J.A., LIM, W.A., WEISSMAN, J.S., QI, L.S. (2013). CRISPR-mediated modular RNAguided regulation of transcription in eukaryotes. Cell 154: 442-451.

GLENN NORTHCUTT, R. (2005). The new head hypothesis revisited. J Exp Zool Part B Mol Dev Evol 304B: 274-297.

GRENIER, J., TEILLET, M.-A., GRIFONE, R., KELLY, R.G., and DUPREZ, D. (2009). Relationship between Neural Crest Cells and Cranial Mesoderm during Head Muscle Development. PLoS One 4: e4381.

GROCOTT, T., TAMBALO, M., and STREIT, A. (2012). The peripheral sensory nervous system in the vertebrate head:A gene regulatory perspective. Dev Bio/370:3-23.

HALL, B.K. (2000). The neural crest as a fourth germ layer and vertebrates as quadroblastic not triploblastic. Evol Dev 2: 3-5.

HALL, B.K. (2009). The Neural Crest and Neural Crest Cells in Vertebrate Development and Evolution (Boston, MA: Springer US).

HAMBURGER, V., and HAMILTON, H.L. (1951). A series of normal stages in the development of the chick embryo. J Morphol 88: 49-92.

HARRIS, M.L., and ERICKSON, C.A. (2007). Lineage specification in neural crest cell pathfinding. Dev Dyn 236: 1-19.

HEASMAN, J., KOFRON, M., and WYLIE, C. (2000). BCatenin Signaling Activity Dissected in the Early Xenopus Embryo: A Novel Antisense Approach. Dev Biol 222: 124-134.

HILTON, I.B., D'IPPOLITO, A.M., VOCKLEY, C.M., THAKORE, P.I., CRAWFORD, G.E., REDDY, T.E., and GERSBACH, C.A. (2015). Epigenome editing by a CRISPRCas9-based acetyltransferase activates genes from promoters and enhancers. Nat Biotechnol 33: 510-517.

HOWARD, E.W., NEWMAN, L.A., OLEKSYN, D.W., ANGERER, R.C., and ANGERER, L.M. (2001). SpKrl: a direct target of beta-catenin regulation required for endoderm differentiation in sea urchin embryos. Development 128: 365-375.

JIANG, W., BIKARD, D., COX, D., ZHANG, F., and MARRAFFINI, L.A. (2013). RNAguided editing of bacterial genomes using CRISPR-Cas systems. Nat Biotechnol 31: 233-239.

JINEK, M., CHYLINSKI, K., FONFARA, I., HAUER, M., DOUDNA, J.A., and CHARPENTIER, E. (2012). A programmable dual-RNA-guided DNA endonuclease in adaptive bacterial immunity. Science 337 : 816-821.

JINEK, M., EAST, A., CHENG, A., LIN, S., MA, E., and DOUDNA, J.A. (2013). RNAprogrammed genome editing in human cells. Elife 2013: e00471.

JOHNSTON, M.C. (1966). A radioautographic study of the migration and fate of cranial neural crest cells in the chick embryo. Anat Rec 156: 143-155.

JOUNG, J.K., and SANDER, J.D. (2013). TALENs: a widely applicable technology for targeted genome editing. Nat Rev Mol Cell Biol 14: 49-55.

KASEMEIER-KULESA, J.C., MCLENNAN, R., ROMINE, M.H., KULESA, P.M., and LEFCORT, F. (2010). CXCR4 Controls Ventral Migration of Sympathetic Precursor Cells. J Neurosci 30: 13078-13088.

KEROSUO, L., NIE, S., BAJPAI, R., and BRONNER, M.E. (2015). Crestospheres:
Long-Term Maintenance of Multipotent, Premigratory Neural Crest Stem Cells. Stem Cell Reports 5: 499-507.

KHUDYAKOV, J., and BRONNER-FRASER, M. (2009). Comprehensive spatiotemporal analysis of early chick neural crest network genes. Dev Dyn 238: 716-723.

KIM, J., LO, L., DORMAND, E., and ANDERSON, D.J. (2003). SOX10 maintains multipotency and inhibits neuronal differentiation of neural crest stem cells. Neuron 38: 17-31.

KIRBY, M.L., and HUTSON, M.R. (2010). Factors controlling cardiac neural crest cell migration. Cell Adh Migr 4: 609-621.

KIRBY, M.L., and WALDO, K.L. (1995). Neural crest and cardiovascular patterning. Circ. Res. 77: 211-215.

KIRBY, M.L., TURNAGE, K.L., and HAYS, B.M. (1985). Characterization of conotruncal malformations following ablation of "cardiac" neural crest. Anat Rec 213: 87-93.

KNECHT, A.K., and BRONNER-FRASER, M. (2002). Induction of the neural crest: a multigene process. Nat Rev Genet 3: 453-461.

KOS, R., REEDY, M.V., JOHNSON, R.L., and ERICKSON, C.A. (2001). The wingedhelix transcription factor FoxD3 is important for establishing the neural crest lineage and repressing melanogenesis in avian embryos. Development 128: 1467-1479.

KRULL, C.E., LANSFORD, R., GALE, N.W., COLLAZO, A., MARCELLE, C., YANCOPOULOS, G.D., FRASER, S.E., and BRONNER-FRASER, M. (1997). Interactions of Eph-related receptors and ligands confer rostrocaudal pattern to trunk neural crest migration. Curr Biol 7: 571-580.

KUDO, T., and SUTOU, S. (2005). Usage of putative chicken U6 promoters for vectorbased RNA interference. J Reprod Dev 51: 411-417.

KULESA, P.M., and FRASER, S.E. (1998). Neural crest cell dynamics revealed by time-lapse video microscopy of whole embryo chick explant cultures. Dev Biol 204: 327-344.

KULESA, P.M., and FRASER, S.E. (2000). in ovo time-lapse analysis of chick hindbrain neural crest cell migration shows cell interactions during migration to the branchial arches. Development 127: 1161-1172.

KULESA, P.M., and GAMMILL, L.S. (2010). Neural crest migration: Patterns, phases and signals. Dev Biol 344: 566-568.

LABOSKY, P.A., and KAESTNER, K.H. (1998). The winged helix transcription factor Hfh2 is expressed in neural crest and spinal cord during mouse development. Mech Dev 76: 185-190.

LAHAV, R., DUPIN, E., LECOIN, L., GLAVIEUX, C., CHAMPEVAL, D., ZILLER, C., and LE DOUARIN, N.M. (1998). Endothelin 3 selectively promotes survival and proliferation of neural crest-derived glial and melanocytic precursors in vitro. Proc Natl Acad Sci USA 95: 14214-14219.

LE LIEVRE, C.S., SCHWEIZER, G.G., ZILLER, C.M., and LE DOUARIN, N.M. (1980). Restrictions of developmental capabilities in neural crest cell derivatives as tested by in vivo transplantation experiments. Dev Biol 77: 362-378.

LIU, J.P., and JESSELL, T.M. (1998). A role for rhoB in the delamination of neural crest cells from the dorsal neural tube. Development 125: 5055-5067.

LUMSDEN, A., SPRAWSON, N., and GRAHAM, A. (1991). Segmental origin and migration of neural crest cells in the hindbrain region of the chick embryo. Development 113: 1281-1291.

MAEDER, M.L., LINDER, S.J., CASCIO, V.M., FU, Y., HO, Q.H., and JOUNG, J.K. (2013). CRISPR RNA - guided activation of endogenous human genes. Nat Methods 10: 977-979.

MALI, P., YANG, L., ESVELT, K.M., AACH, J., GUELL, M., DICARLO, J.E., NORVILLE, J.E., and CHURCH, G.M. (2013a). RNA-guided human genome engineering via Cas9. Science 339: 823-826.

MALI, P., AACH, J., STRANGES, P.B., ESVELT, K.M., MOOSBURNER, M., KOSURI, S., YANG, L., and CHURCH, G.M. (2013b). Cas9 transcriptional activators for target specificity screening and paired nickases for cooperative genome engineering. Nat Biotechno/ 31: 833-838.

MARTIK, M. and BRONNER, M.E. (2017). Regulatory Logic Underlying Diversification of the Neural Crest. Trends Genet 33: 715-727.

MINOUX, M., and RIJLI, F.M. (2010). Molecular mechanisms of cranial neural crest cell migration and patterning in craniofacial development. Development 137 2605-2621.

MONSORO-BURQ, A.-H., FLETCHER, R.B., and HARLAND, R.M. (2003). Neural crest induction by paraxial mesoderm in Xenopus embryos requires FGF signals. Development 130: 3111-3124. 
MORENO-MATEOS, M.A., VEJNAR, C.E., BEAUDOIN, J., FERNANDEZ, J.P., MIS, E.K., KHOKHA, M.K., and GIRALDEZ, A.J. (2015). CRISPRscan: designing highly efficient sgRNAs for CRISPR-Cas9 targeting in vivo. Nat Methods 12: 982-988.

MURAI, H., TADOKORO, R., SAKAI, K.I., and TAKAHASHI, Y. (2015). in ovo gene manipulation of melanocytes and their adjacent keratinocytes during skin pigmentation of chicken embryos. Dev Growth Differ 57: 232-241.

NAKAMURA, H., and AYER-LE LIEVRE, C.S. (1982). Mesectodermal capabilities of the trunk neural crest of birds. J Embryol Exp Morphol 70: 1-18.

NASEVICIUS, A., and EKKER, S.C. (2000). Effective targeted gene "knockdown" in zebrafish. Nat Genet 26: 216-220.

NEWGREEN, D.F., and GOODAY, D. (1985). Control of the onset of migration of neural crest cells in avian embryos - Role of $\mathrm{Ca}++$ +-dependent cell adhesions. Cell Tissue Res 239: 329-336.

NEWGREEN, D.F., SCHEEL, M., and KASTNER, V. (1986). Morphogenesis of sclerotome and neural crest in avian embryos - In vivo and in vitro studies on the role of notochordal extracellular material. Cell Tissue Res 244: 299-313.

NISHIBATAKE, M., KIRBY, M.L., and VAN MIEROP, L.H. (1987). Pathogenesis of persistent truncus arteriosus and dextroposed aorta in the chick embryo after neural crest ablation. Circulation 75: 255-264.

NITZAN, E., PFALTZGRAFF, E.R., LABOSKY, P.A., and KALCHEIM, C. (2013). Neural crest and Schwann cell progenitor-derived melanocytes are two spatially segregated populations similarly regulated by Foxd3. Proc Natl Acad Sci USA 110: 12709-12714.

NODEN, D.M. (1975). An analysis of the migratory behavior of avian cephalic neural crest cells. Dev Biol 42: 106-130.

NODEN, D.M. (1978). The control of avian cephalic neural crest cytodifferentiation. Dev Biol 67: 296-312.

OSORIO, L., TEILLET, M.-A., and CATALA, M. (2009). Role of noggin as an upstream signal in the lack of neuronal derivatives found in the avian caudal-most neural crest. Development 136: 1717-1726.

OSUMI-YAMASHITA, N., NINOMIYA, Y., DOI, H., and ETO, K. (1996). Rhombomere formation and hind-brain crest cell migration from prorhombomeric origins in mouse embryos. Dev Growth Differ 38: 107-118.

PEREZ-PINERA, P., KOCAK, D.D., VOCKLEY, C.M., ADLER, A.F., KABADI, A.M., POLSTEIN, L.R., THAKORE, P.I., GLASS, K.A., OUSTEROUT, D.G., LEONG, K.W., GUILAK, F., CRAWFORD, G.E., REDDY, T.E., GERSBACH, C.A. (2013). RNA-guided gene activation by CRISPR-Cas9-based transcription factors. Nat Methods 10: 973-976.

PRICE, J., TURNER, D., and CEPKO, C. (1987). Lineage analysis in the vertebrate nervous system by retrovirus- mediated gene transfer. Proc Natl Acad Sci USA 84: $156-160$

QI, L.S., LARSON, M.H., GILBERT, L. A, DOUDNA, J. A, WEISSMAN, J.S., ARKIN, A.P., and LIM, W. A (2013). Repurposing CRISPR as an RNA-guided platform for sequence-specific control of gene expression. Cell 152: 1173-1183.

REN, X., YANG, Z., XU, J., SUN, J., MAO, D., HU, Y., YANG, S.-J., QIAO, H.-H., WANG, X., HU, Q., et al. (2014). Enhanced Specificity and Efficiency of the CRISPR/Cas9 System with Optimized sgRNA Parameters in Drosophila. Cell Rep 9: 1151-1162.

RICKMANN, M., FAWCETT, J.W., and KEYNES, R.J. (1985). The migration of neural crest cells and the growth of motor axons through the rostral half of the chick somite. J Embryol Exp Morphol 90: 437-455.

ROELLIG, D., TAN-CABUGAO, J., ESAIAN, S., and BRONNER, M.E. (2017). Dynamic transcriptional signature and cell fate analysis reveals plasticity of individual neural plate border cells. Elife 6: 331-342.

SAITO, D., and TAKAHASHI, Y. (2015). Sympatho-adrenal morphogenesis regulated by the dorsal aorta. Mech Dev 138: 2-7.

SAITO, D., TAKASE, Y., MURAI, H., and TAKAHASHI, Y. (2012). The dorsal aorta initiates a molecular cascade that instructs sympatho-adrenal specification. Science 336: 1578-1581.

SANES, J.R. (1989). Analysing cell lineage with a recombinant retrovirus. Trends Neurosci 12: 21-28.

SANES, J.R., RUBENSTEIN, J.L., and NICOLAS, J.F. (1986). Use of a recombinant retrovirus to study post-implantation cell lineage in mouse embryos. EMBO J 5 , 3133-3142.

SASAI, N., MIZUSEKI, K., and SASAI, Y. (2001). Requirement of FoxD3-class signal- ing for neural crest determination in Xenopus. Development 128: 2525-2536.

SAUKA-SPENGLER, T., and BRONNER-FRASER, M. (2008). A gene regulatory network orchestrates neural crest formation. Nat Rev Mol Cell Biol 9: 557-568.

SCHULTE-MERKER, S., and STAINIER, D.Y.R. (2014). Out with the old, in with the new: reassessing morpholino knockdowns in light of genome editing technology. Development 141: 3103-3104.

SELA-DONENFELD, D., and KALCHEIM, C. (1999). Regulation of the onset of neural crest migration by coordinated activity of BMP4 and Noggin in the dorsal neural tube. Development 126: 4749-4762.

SERBEDZIJA, G.N., BRONNER-FRASER, M., and FRASER, S.E. (1989). A vital dye analysis of the timing and pathways of avian trunk neural crest cell migration. Development 106: 809-816.

SERBEDZIJA, G.N., FRASER, S.E., and BRONNER-FRASER, M. (1990). Pathways of trunk neural crest cell migration in the mouse embryo as revealed by vital dye labelling. Development 108: 605-612.

SHALEM, O., SANJANA, N.E., and ZHANG, F. (2015). High-throughput functional genomics using CRISPR-Cas9. Nat Rev Genet 16: 299-311.

SHYAMALA, K., YANDURI, S., GIRISH, H.C., and MURGOD, S. (2015). Neural crest: The fourth germ layer. J Oral Maxillofac Pathol 19: 221-229.

SIMOES-COSTA, M., and BRONNER, M.E. (2016). Reprogramming of avian neural crest axial identity and cell fate. Science 352: 1570-1573

SIMÕES-COSTA, M., and BRONNER, M.E. (2013). Insights into neural crest development and evolution from genomic analysis. Genome Res 23: 1069-1080.

SIMÕES-COSTA, M., and BRONNER, M.E. (2015). Establishing neural crest identity: a gene regulatory recipe. Development 142: 242-257.

SIMÕES-COSTA, M., TAN-CABUGAO, J., ANTOSHECHKIN, I., SAUKA-SPENGLER, T., and BRONNER, M.E. (2014). Transcriptome analysis reveals novel players in the cranial neural crest gene regulatory network. Genome Res 24: 281-290.

SIMÕES-COSTA, M., STONE, M., and BRONNER, M.E. (2015). Axud1 Integrates Wnt Signaling and Transcriptional Inputs to Drive Neural Crest Formation. Dev Cell 34: 544-554.

SIMÕES-COSTA, M.S., MCKEOWN, S.J., TAN-CABUGAO, J., SAUKA-SPENGLER, T., and BRONNER, M.E. (2012). Dynamic and Differential Regulation of Stem Cell Factor FoxD3 in the Neural Crest Is Encrypted in the Genome. PLoS Genet 8: e1003142.

SIT, S-T., and MANSER, E. (2011). Rho GTPases and their role in organizing the actin cytoskeleton. J Cell Sci 124: 679-683.

SMITH, J. (1990). The avian neural crest as a model system for the study of cell lineages. Int J Dev Biol 34: 157-162.

STEMPLE, D.L., and ANDERSON, D.J. (1992). Isolation of a stem cell for neurons and glia from the mammalian neural crest. Cell 71: 973-985.

STEVENTON, B., CARMONA-FONTAINE, C., and MAYOR, R. (2005). Genetic network during neural crest induction: From cell specification to cell survival. Semin Cell Dev Biol 16: 647-654.

STEVENTON, B., ARAYA, C., LINKER, C., KURIYAMA, S., and MAYOR, R. (2009). Differential requirements of BMP and Wnt signalling during gastrulation and neurulation define two steps in neural crest induction. Development 136: 771-779.

STEWART, R.A., ARDUINI, B.L., BERGHMANS, S., GEORGE, R.E., KANKI, J.P., HENION, P.D., and LOOK, A.T. (2006). Zebrafish foxd3 is selectively required for neural crest specification, migration and survival. Dev Biol 292: 174-188.

STOLFI, A., GANDHI, S., SALEK, F., and CHRISTIAEN, L. (2014). Tissue-specific genome editing in Ciona embryos by CRISPR/Cas9. Development141:4115-4120.

STOLLER, J.Z., and EPSTEIN, J.A. (2005). Cardiac neural crest. Semin Cell Dev Biol 16: 704-715.

STUHLMILLER, T.J., and GARCÍA-CASTRO, M.I. (2012). Current perspectives of the signaling pathways directing neural crestinduction. Cell Mol Life Sci 69:3715-3737.

TAKAHASHI, K., TANABE, K., OHNUKI, M., NARITA, M., ICHISAKA, T., TOMODA, K., and YAMANAKA, S. (2007). Induction of pluripotent stem cells from adult human fibroblasts by defined factors. Cell 131: 861-872.

THÉVENEAU, E., and MAYOR, R. (2011). Collective cell migration of the cephalic neural crest: The art of integrating information. Genesis 49: 164-176.

THÉVENEAU, E., DUBAND, J.-L., ALTABEF, M., FAUQUETTE, W., and POLLET, I. (2007). Ets-1 Confers Cranial Features on Neural Crest Delamination. PLoS One 2: e1142. 
THOMAS, A.J., and ERICKSON, C. A (2009). FOXD3 regulates the lineage switch between neural crest-derived glial cells and pigment cells by repressing MITF through a non-canonical mechanism. Development 136: 1849-1858.

TOSNEY, K.W. (2004). Long-Distance Cue from Emerging Dermis Stimulates Neural Crest Melanoblast Migration. Dev Dyn 229: 99-108.

TRAINOR, P.A., MELTON, K.R., and MANZANARES, M. (2003). Origins and plasticity of neural crest cells and their roles in jaw and craniofacial evolution. Int $J$ Dev Biol 47: 541-553.

TRENTIN, A., GLAVIEUX-PARDANAUD, C., LE DOUARIN, N.M., and DUPIN, E. (2004). Self-renewal capacity is a widespread property of various types of neural crest precursor cells. Proc Natl Acad Sci USA 101: 4495-4500.

TUCKER, R.P. (2004). Neural crest cells: a model for invasive behavior. Int J Biochem Cell Biol 36: 173-177.

WANG, H.U., and ANDERSON, D.J. (1997). Eph family transmembrane ligands can mediate repulsive guidance of trunk neural crest migration and motor axon outgrowth. Neuron 18: 383-396.

WANG, T., WEI, J.J., SABATINI, D.M., and LANDER, E.S. (2014). Genetic screens in human cells using the CRISPR-Cas9 system. Science 343: 80-84.
WESTON, J.A. (1963). A radioautographic analysis of the migration and localization of trunk neural crest cells in the chick. Dev Biol 6: 279-310.

WESTON, J.A., and BUTLER, S.L. (1966). Temporal factors affecting localization of neural crest cells in the chicken embryo. Dev Biol 14: 246-266.

WIEDENHEFT, B., STERNBERG, S.H., and DOUDNA, J.A. (2012). RNA-guided genetic silencing systems in bacteria and archaea. Nature 482: 331-338.

WILLIAMS, R.M., SENANAYAKE, U., ARTIBANI, M., TAYLOR, G.O., WELLS, D., AHMED, A.A., and SAUKA-SPENGLER, T. (2018). Genome and epigenome engineering CRISPR toolkit for in vivo modulation of cis-regulatory interactions and gene expression in the chicken embryo. Development 145: dev160333

WISE, T.G., SCHAFER, D.J., LAMBETH, L.S., TYACK, S.G., BRUCE, M.P., MOORE, R.J., and DORAN, T.J. (2007). Characterization and Comparison of Chicken U6 Promoters for the Expression of Short Hairpin RNAs. Anim Biotechno 18: 153-162.

YANG, Z., LIU, N., and LIN, S. (2001). A Zebrafish Forebrain-Specific Zinc Finger Gene Can Induce Ectopic dlx2 and dlx6 Expression. Dev Biol 231: 138-148.

ZHANG, F., CONG, L., LODATO, S., KOSURI, S., CHURCH, G.M., and ARLOTTA, P. (2011). Efficient construction of sequence-specific TAL effectors for modulating mammalian transcription. Nat Biotechnol 29: 149-153. 


\section{Further Related Reading, published previously in the Int. J. Dev. Biol.}

Contribution of cranial neural crest cells to mouse skull development

Taofen Wu, Guiqian Chen, Fei Tian and Hong-Xiang Liu

Int. J. Dev. Biol. (2017) 61: 495-503

https://doi.org/10.1387/ijdb.170051gc

Cell fate decisions during neural crest ontogeny

Chaya Kalcheim and Deepak Kumar

Int. J. Dev. Biol. (2017) 61: 195-203

https://doi.org/10.1387/ijdb.160196ck

Trunk neural crest cells: formation, migration and beyond

Guillermo A. Vega-lopez, Santiago Cerrizuela and Manuel J. Aybar

Int. J. Dev. Biol. (2017) 61: 5-15

https://doi.org/10.1387/ijdb.160408gv

Evolution of the vertebrate claudin gene family: insights from a basal vertebrate, the sea lamprey

Christian Mukendi, Nicholas Dean, Rushil Lala, Jeramiah Smith, Marianne E. Bronner and Natalya V. Nikitina

Int. J. Dev. Biol. (2016) 60: 39-51

https://doi.org/10.1387/ijdb.150364nn

Clonal analyses in the anterior pre-placodal region: implications for the early lineage bias of placodal progenitors

Sujata Bhattacharyya and Marianne E. Bronner

Int. J. Dev. Biol. (2013) 57: 753-757

https://doi.org/10.1387/ijdb.130155mb

Expression of Sox family genes in early lamprey development

Benjamin R. Uy, Marcos Simoes-Costa, Tatjana Sauka-Spengler and Marianne E. Bronner Int. J. Dev. Biol. (2012) 56: 377-383

https://doi.org/10.1387/ijdb.113416bu

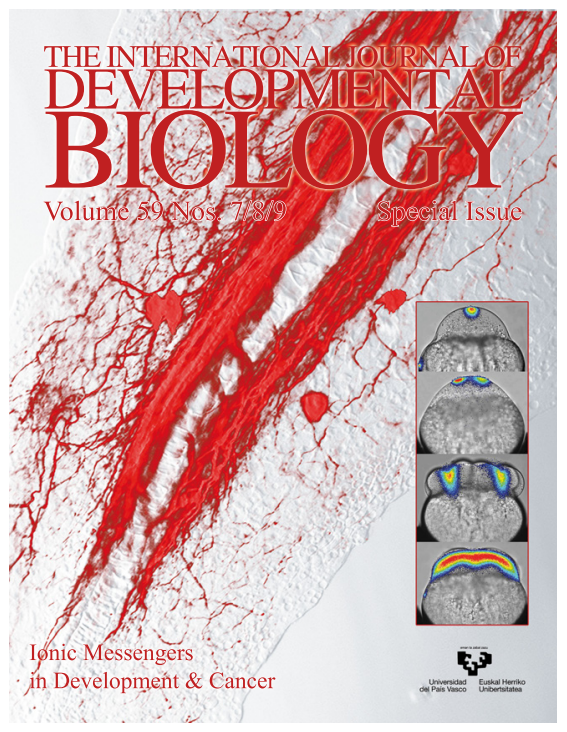

5 yr ISI Impact Factor $(2016)=2.421$
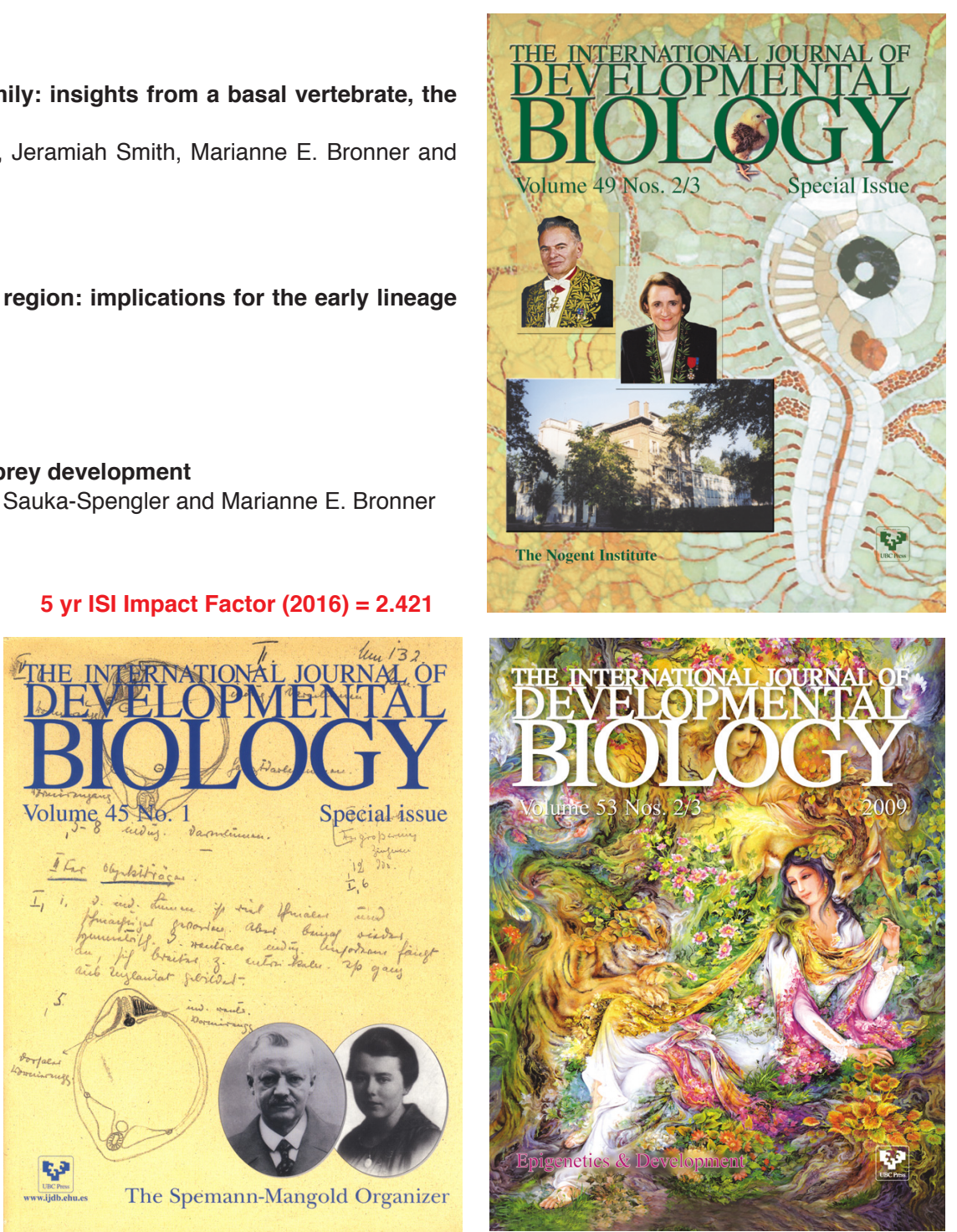